ROCZNIKI HUMANISTYCZNE

Tom LXVIII, zeszyt 2 - 2020

DOI: http://dx.doi.org/10.18290/rh20682-7

JANUSZ R. BUDZIŃSKI

\title{
ROSYJSKIE PRZEDSTAWICIELSTWA KONSULARNE I PODSTAWY PRAWNE ICH FUNKCJONOWANIA W LATACH 1809-1914
}

\author{
ZARYS PROBLEMATYKI
}

Na początku XIX wieku Cesarstwo Rosyjskie, tak jak i inne ówczesne państwa, posiadało swoich przedstawicieli konsularnych w różnych krajach, z którymi łączyły je stosunki polityczne, gospodarcze i dynastyczne. W tym okresie konsulowie rosyjscy podlegali kierownictwu Kolegium Spraw Zagranicznych (dalej KSZ), które odpowiadało, do czasu powołania w $1802 \mathrm{r}$. Ministerstwa Spraw Zagranicznych, za politykę zagraniczną Rosji ${ }^{1}$. W swojej działalności kierowali się instrukcjami, które były im wręczane przy mianowaniu na placówkę konsularną, co spowodowane było brakiem oficjalnego dokumentu określającego ich kompetencje. Ponadto prawa i miejsca wysyłania konsulów były określane przez umowy Cesarstwa Rosyjskiego z innymi państwami.

Niniejszy artykuł ma na celu przybliżenie procesu powstawania podstaw prawnych funkcjonowania rosyjskich przedstawicielstw i przedstawicieli konsularnych w latach 1809-1914. Cezura ta została wybrana nieprzypadkowo. Obejmuje ona lata panowania ostatnich pięciu Romanowów, kiedy to podjęto prace m.in. nad reorganizacją rosyjskiego systemu administracji państwowej, związanej z kontaktami międzynarodowymi, i co za tym idzie -

Dr hab. JANUSZ R. BUDZIŃSKI - Uniwersytet Jana Kochanowskiego w Kielcach Filia w Piotrkowie Trybunalskim; adres do korespondencji: 90-300 Piotrków Trybunalski, ul. J. Słowackiego 114/118; e-mail: jbudzinski@ujk.edu.pl; ORCID: https://orcid.org/0000-0001-9365-406X.

${ }^{1}$ Szerzej o Kolegium Spraw Zagranicznych oraz o zależnościach między Ministerstwem Spraw Zagranicznych i KSZ zob. w: J.R. BuDZIŃSKI, Ministerstwo Spraw Zagranicznych Rosji w okresie panowania Mikołaja II (1894-1917). Przemiany organizacyjne, Piotrków Trybunalski 2015, s. 24-48 i 51-52. 
kodyfikacją prawa dotyczącego tak działalności centralnych organów, jak i przedstawicielstw zagranicznych. Dodatkowo można zauważyć, że dolna granica (rok 1809) to czas rozpoczęcia prac zmierzających do uporządkowania spraw związanych ze służbą konsularną za panowania Aleksandra I. Z kolei rok 1914 stanowi zamknięcie poruszanej w artykule problematyki, gdyż w czerwcu zawieszono na okres wakacji prace nad reformą służby konsularnej. Wybuch I wojny światowej spowodowal, że do kwestii związanych z wprowadzaniem zmian w rosyjskim systemie konsularnym nie wrócono.

Jak już zostało wspomnianej, w 1809 r. (3/15 maja ${ }^{2}$ ) Aleksander I zapoczątkował reformę $\mathrm{w}$ kwestiach dotyczących działalności konsularnej. Została wówczas utworzona Ekspedycja Spraw Konsularnych, która była podporządkowana bezpośrednio ministrowi spraw zagranicznych. Jej zadaniem było utrzymywanie kontaktów i prowadzenie korespondencji tak z rosyjskimi przedstawicielami konsularnymi, jak i z przedstawicielami konsularnymi innych państw przebywającymi na terenie Cesarstwa Rosyjskiego. Ponadto przygotowywała ona instrukcje i nadzorowała ich wykonanie, a także rozpatrywała kwestie nagród oraz spraw dotyczących handlu i żeglugi morskiej ${ }^{3}$. Pojawienie się Ekspedycji Spraw Konsularnych spowodowało, że sprawy konsularne wyszły spod kierownictwa KSZ.

$\mathrm{Na}$ dokument określający zakres działalności przedstawicieli konsularnych trzeba jednak było poczekać do 1820 r. Wówczas Aleksander I, 25 października/7 listopada 1820 r., zatwierdził Regulamin Konsularny. Od tej chwili na tym oficjalnym akcie państwowym opierała się działalność rosyjskich przedstawicielstw konsularnych. Dodać można, że w nim po raz pierwszy wskazano prawa i obowiązki konsulów w sprawach dyplomatycznych, handlowych i prawnych ${ }^{4}$. Przede wszystkim obowiązki te zawierały się w obronie interesów rosyjskiego handlu i praw poddanych rosyjskich za granicą. Wyróżniono cztery kategorie konsulów, które tworzyli konsulowie generalni, konsulowie, wicekonsulowie, sekretarze. Wicekonsulowie mogli być zarówno samodzielnymi urzędnikami w granicach swoich okręgów, jak i młodszymi urzędnikami w konsulatach generalnych i konsulatach.

\footnotetext{
${ }^{2}$ Pierwsza data według obowiązującego w Rosji kalendarza juliańskiego, druga - obowiązującego w świecie zachodnim kalendarza gregoriańskiego.

${ }^{3}$ Очерк истории Министерства иностранных дел 1802-1902, Санкт-Петербург 1902, s. 94; А. ШАПКИНА, Образование МИД и деятельность российской дипломатии в первой четверти XIX в., w: Очерки истории Министерства Иностранных Дел России 860-1917 г2., т. 1, s. 256; J.R. BUDZIŃSKI, Ministerstwo Spraw Zagranicznych Rosji, s. 41-42.

${ }^{4}$ Очерк истории Министерства, s. 98.
} 
Oprócz Regulaminu Konsularnego obowiązki i miejsca wysyłania konsulów określały, tak jak wcześniej, umowy Cesarstwa Rosyjskiego z innymi państwami. Konsulowie byli mianowani na podstawie ukazów cesarskich, uwzględniających sugestie w tej kwestii MSZ. Otrzymywali patenty w języku rosyjskim i w języku kraju pobytu lub języku francuskim ${ }^{5}$. Ponadto konsul przed udaniem się na swoją placówkę powinien był otrzymać pozwolenie od rządu (lub monarchy) kraju docelowego na wykonywanie funkcji konsula - tzw. egzekwatur. Za moment przystąpienia do pełnienia obowiązków uznawano chwilę złożenia przysięgi na wierność cesarzowi rosyjskiemu. Po przybyciu na miejsce przeznaczenia konsul był zobowiązany złożyć wizytę przedstawicielom lokalnych władz. Na budynku konsulatu wywieszano flagę konsularną, konsul posiadał również specjalną pieczęć dla poświadczania dokumentów ${ }^{6}$.

Regulamin konsularny z 1820 r. szczegółowo wyliczał obowiązki konsulów w kwestiach obrony interesów rosyjskiego handlu. Konsulowie winni byli powiadamiać centralę o przypłynięciu i wypłynięciu rosyjskich statków, ich ładunku, przekazywać informacje o opłatach celnych, cenach towarów, kursach weksli itp. Ważnym obowiązkiem było informowanie rosyjskich kupców o lokalnych obyczajach handlowych, cenach, rady w sprawach realizacji zakupu towarów. Ponadto konsulowie mieli sprawować opiekę nad poddanymi rosyjskimi, którzy znaleźli się na terenie im podległym. W razie potrzeby rekomendować ich lokalnym władzom, chronić przed ich samowolą, okazywać pomoc w razie choroby, umieszczać w szpitalu, wysyłać do Rosji marynarzy, których okręty zatonęły ${ }^{7}$.

Do obowiązków konsulów należało również wydawanie wiz i paszportów poddanym rosyjskim, różnorodnych zaświadczeń, aktów poświadczających zawarcie związku małżeńskiego, narodziny dziecka, śmierć, rozwiązywanie spraw spadkowych i innych. Celem zapisywania aktów, informacji o okrętach, pobieranych opłatach konsul był zobowiązany prowadzić sześć ksiąg. Wszystkie konsularne opłaty etatowy konsul przesyłał do skarbu państwa, a nieetatowy, który nie otrzymywał uposażenia od państwa, brał je na swoje potrzeby.

\footnotetext{
${ }^{5}$ Język francuski był w XIX wieku ogólnie przyjęty w stosunkach międzynarodowych. Swą funkcję języka dyplomacji zaczął tracić dopiero pod koniec XIX wieku na rzecz języków narodowych. Problem ten poruszono m.in. w: J.R. BudzIŃski, Piewczeskij Most. Z dziejów dyplomacji Imperium Rosyjskiego w latach 1802-1914, Piotrków Trybunalski 2017, s. 25-30.

${ }^{6}$ А. ШАПКИНА, Образование МИД и деятельность, s. 272; zob. też Б. ГРИГОРьЕВ, Повседневная жизнь иарских дипломатов в ХІХ веке, Москва 2010, s. 349-350.

${ }^{7}$ А. ШАПКИНА, Образование МИД и деятельность, s. 273.
} 
Pod koniec panowania Aleksandra I, w 1825 r., Cesarstwo Rosyjskie posiadało 34 konsulaty generalne (19 znajdowało się w Europie, pozostałe w Afryce - Egipt, Azji - Persja, Smyrna, Trapezunt, USA - Filadelfia) oraz 21 konsulatów, 11 wicekonsulatów i trzech agentów konsularnych ${ }^{8}$.

Następne zmiany dotyczące rosyjskich przedstawicielstw konsularnych nastąpiły za panowania Mikołaja I. Objęły one przede wszystkim szczebel centralny, co związane było z wydanym 10/22 kwietnia 1832 r. ukazem o reorganizacji centralnego zarządu MSZ ${ }^{9}$. Powołano Departament Kontaktów Wewnętrznych, który odpowiadał za kontakty handlowe $\mathrm{z}$ krajami europejskimi i Ameryką. Podlegały mu także kwestie prawne, konsularne, sprawy kwarantanny ${ }^{10}$.

Jeśli chodzi o podstawy prawne funkcjonowania rosyjskich przedstawicielstw konsularnych w latach rządów Mikołaja I, to działały one na podstawie wspomnianego wyżej Regulaminu konsularnego i umów dwustronnych między Cesarstwem Rosyjskim a innymi państwami.

Za panowania Mikołaja I zreorganizowano sieć placówek zagranicznych MSZ, a tym samym zmieniła się ich liczba. Po kończącym w 1829 r. wojnę rosyjsko-turecką pokoju w Adrianopolu rozszerzono sieć rosyjskich konsulatów na Bliskim Wschodzie ${ }^{11}$. W 1830 r. zostały utworzone nowe placówki konsularne w Grecji (Saloniki, Dardanele) i Egipcie. W związku z dalszym rozwojem stosunków z państwami leżącymi na Półwyspie Bałkańskim w 1838 r. otworzono konsulat w Belgradzie oraz przedstawicielstwa w Sliwnie, Warnie i Adrianopolu. W 1839 r. utworzono generalne konsulaty w Serbii, w 1842 r. na Korfu, w 1843 r. w Bejrucie (Azja Mniejsza), który swoją jurysdykcją obejmował Syrię i Palestynę, a w 1847 r. w Adrianopolu. W 1846 r. zlikwidowano stanowisko generalnego konsula w Krakowie.

Dodać można, że tylko do 1833 r. powstały 24 konsulaty generalne, 35 konsulatów i 36 wicekonsulatów. Oprócz tego w rosyjskiej służbie konsularnej istniały stanowiska komisarzy do spraw handlowych i agentów. Cesarstwo Rosyjskie posiadało także tzw. nieetatowych konsulów, których powo-

\footnotetext{
${ }^{8}$ Очерк истории Министерства, s. 98; А. ШАПкинА, Образование МИД и деятельность, s. 272.

${ }^{9}$ Reorganizację, do której wówczas doszło, szczegółowo omówiono w: J.R. BuDziŃSKI, Ministerstwo Spraw Zagranicznych Rosji, s. 52-57.

${ }^{10} \mathrm{O}$ obowiązkach konsulów rosyjskich i ich podległości służbowej w tym czasie szerzej zob. J.R. BUDZIŃSKI, Ministerstwo Spraw Zagranicznych Rosji, s. 69.

${ }^{11}$ Pod tym pojęciem w Cesarstwie Rosyjskim rozumiano obszar Półwyspu Bałkańskiego i Azji Mniejszej.
} 
ływał spośród lokalnych mieszkańców konsul generalny. Od niego otrzymywali patent podpisany przez ministra spraw zagranicznych. Służyli oni w odległych, czasami egzotycznych (z rosyjskiego punktu widzenia) punktach świata. Można wymienić tu Wyspy Kanaryjskie, Przylądek Dobrej Nadziei, Baleary, Szkocję czy Wyspy Alandzkie.

W 1854 r. liczba nieetatowych placówek konsularnych uległa zwiększeniu, w związku z czym Cesarstwo Rosyjskie posiadało 86 nieetatowych konsulów, wicekonsulów i agentów konsularnych ${ }^{12}$. Spowodowane to było ograniczeniem środków finansowych na działalność etatowych przedstawicielstw. To z kolei spowodowało, że w 1855 r., który był ostatnim rokiem panowania Mikołaja I, liczba etatowych placówek konsularnych uległa zmniejszeniu. Funkcjonowało wówczas 18 konsulatów generalnych, 20 konsulatów, 5 wicekonsulatów.

W pierwszych latach panowania Aleksandra II, do 1857 r., Cesarstwo Rosyjskie posiadało 30 konsulatów generalnych, 31 etatowych i 14 nieetatowych konsulatów, 15 etatowych i 123 nieetatowe wicekonsulaty i 9 agentów konsularnych. Tym samym można stwierdzić, że liczba etatowych, jak i nieetatowych przedstawicielstw konsularnych w porównaniu z $1855 \mathrm{r}$. uległa zwiększeniu.

W początkowym okresie rządów Aleksandra II pojawił się nowy akt dotyczący działalności i obowiązków rosyjskich przedstawicieli konsularnych. Był to wydany 23 grudnia 1858/4 stycznia 1859 r. Regulamin dla rosyjskich konsulów w Europie i Ameryce ${ }^{13}$.

Głównym zadaniem konsulów wszystkich kategorii miała być troska o rosyjski handel i żeglugę $\mathrm{w}$ powierzonych im okręgach, a tym samym ochrona handlowych interesów Cesarstwa Rosyjskiego. Aby to osiągnąć, mieli oni służyć pomocą rosyjskim statkom handlowym, pośredniczyć w sporach dotyczących spraw handlowych poddanych rosyjskich i nadzorować przestrzeganie praw Rosji wynikających z zawartych przez nią traktatów.

\footnotetext{
${ }^{12}$ Очерк истории Министерства, s. 132; Е. КУдРяВЦЕВА, В. ПоНОМАРЕВ, Дипломатия и МИД России во второй четверти ХІХ в., w: Очерки истории Министерства, s. 337.

${ }^{13}$ Полное собрание законов Российской империи (dalej: ПСЗРИ), t. 33, часть 21858 г., Санкт Петербург 1860, s. 531-553. Regulamin ten obowiązywał jeszcze w 1902 r. Obejmował 111 artykułów i, tak jak wskazywała jego nazwa, obowiązywał tylko konsulów rosyjskich w Europie i Ameryce. Dla konsulów na Wschodzie, w Persji i w tzw. Lewancie zachowały moc przepisy regulaminu handlowego - zob. Очерк истории Министерства, s. 168; В. ХевролинА, Министерство Иностранных Дел России в период реформ (1856-1878), w: Очерки истории Министерства, т. 1, s. 427-428. Zauważyć należy, że żadne z wymienionych tu opracowań nie przytaczało zapisów wspomnianego Regulaminu handlowego.
} 
Mieli również czuwać nad prawidłowym przygotowaniem dokumentów od strony formalnej, obserwować wypływające statki handlowe, świadczyć pomoc w przypadku rozbicia lub awarii statku.

Równie ważnym zadaniem, jakie stało przed każdym konsulem, była dbałość o dobre imię Cesarstwa Rosyjskiego. W związku z tym wszyscy konsulowie mieli pilnować, aby żaden poddany rosyjski nie naruszył przyjętych zobowiązań i nie oszukiwał swoich kontrahentów ${ }^{14}$. W Regulaminie wiele uwagi poświęcono również pomocy ze strony konsulów dla rosyjskich okrętów wojennych ${ }^{15}$.

Istotnym punktem regulaminu był zapis o obowiązku wysyłania przez konsulów do Ministerstwa Finansów, co cztery miesiące, informacji o rosyjskiej aktywności handlowej w miejscu podległym ich jurysdykcji, o cenach towarów, kursach weksli, taryfach i traktatach handlowych. Mieli również gromadzić i przesyłać informacje o gospodarce podległego im okręgu. Tym samym można stwierdzić, że obowiązki nałożone w Regulaminie na konsulów miały sprzyjać rozszerzeniu działalności handlowej i gospodarczej Cesarstwa Rosyjskiego wszędzie tam, gdzie znajdowały się jego przedstawicielstwa konsularne. Podkreślić należy, że sprawozdania o pracy konsulatów były wysyłane również do Ministerstwa Spraw Zagranicznych.

Regulamin zawierał także tradycyjne zapisy mówiące o ochronie przez konsulów praw poddanych rosyjskich wobec władz lokalnych, pomocy w razie choroby i śmierci, trosce o dzieci, które pozostały bez rodziców itp. Określał także zasady kontaktów konsula z lokalnymi władzami, mówił o sposobie prowadzenia dokumentacji, zawierał opis pieczęci konsularnej i flagi ${ }^{16}$.

Regulamin z 1858/1859 r. mógł być zastosowany w ogólnych zapisach również do służby konsularnej na Wschodzie. Ponieważ jednak dochodziły tutaj jeszcze kwestie polityczne, dlatego rosyjscy przedstawiciele konsularni w tym rejonie działali przede wszystkim na podstawie traktatów zawartych przez Cesarstwo Rosyjskie z krajami Wschodu. W kwestiach dotyczących spraw gospodarczych opierali się na Regulaminie handlowym.

W latach 1870-1877 w Ministerstwie Spraw Zagranicznych opracowano projekt nowego Regulaminu konsularnego. Następnie rozesłano go celem konsultacji do ważniejszych konsulów. Wspomnianego regulaminu nie udało się wprowadzić w życie za panowania Aleksandra II, ponieważ rosyjscy przedstawiciele konsularni nie spieszyli się z jego odesłaniem.

\footnotetext{
${ }^{14}$ ПСЗРИ, t. 33, часть 21858 г., s. 539-553.

${ }^{15}$ Tamże, s. 535-538.

${ }^{16}$ Tamże, s. 534.
} 
Za panowania Aleksandra II sieć przedstawicielstw zagranicznych przeszła szereg zmian. Związane było to $\mathrm{z}$ zadaniami politycznymi i ekonomicznymi, jakie stanęły w tym czasie przed Cesarstwem Rosyjskim. Powołanie nowych lub reorganizacja starych placówek miała te zadania ułatwić. Dotyczyło to przede wszystkim Bałkanów, Bliskiego i Dalekiego Wschodu, Ameryki Łacińskiej czy Oceanii. Ważnym czynnikiem, który wpływał na zmiany w obrębie przedstawicielstw, były też zmiany na mapie politycznej Europy ${ }^{17}$.

Zwiększenie wpływów politycznych na Bliskim Wschodzie spowodowało konieczność utworzenia nowych konsulatów na podległych władzy tureckiej terenach bałkańskich, Azji Mniejszej i afrykańskich. W związku z powyższym na Bałkanach od końca lat pięćdziesiątych XIX wieku zaczęły powstawać nowe placówki konsularne. W 1856 r. utworzono konsulaty w Sarajewie i Szkodrze, w 1857 r. w Warnie i Janinie, w 1859 r. w Mostarze, w 1860 r. na Krecie oraz wicekonsulat w Filippopolu (Płowdiw). W 1872 r. na Bałkanach były już 23 konsulaty wszystkich rang. Miały one przede wszystkim zadania polityczne - obronę praw prawosławnych chrześcijan ${ }^{18}$.

Zwiększeniu uległa też liczba konsulatów w basenie Morza Śródziemnego, Azji Mniejszej i w Afryce. W 1857 r. utworzono wicekonsulaty w Bagdadzie, Batumie, w 1860 r. w Algierze, w 1861 r. w Oranie. W 1866 r. powstał nieetatowy konsulat $\mathrm{w}$ Tunisie i konsulaty w Trieście i Wenecji. W 1867 r. utworzono wicekonsulat w Gibraltarze i konsulat w Livorno. W 1868 r. powołano do życia konsulat w Port Saidzie ${ }^{19}$. Wszystkie te kroki podjęto w związku z rozwojem rosyjskiego handlu. Z bardziej egzotycznych miejsc, w których powstały w latach 50., 60. i 70. XIX w. rosyjskie placówki konsularne, można wymienić: wicekonsulaty w Honolulu i na Wyspie św. Heleny (1858 r.), konsulat w Callao (1862 r.), agencje konsularne na Antylach (1872 r. $)^{20}$.

Przyłączenie terytoriów na Dalekim Wschodzie wywołało potrzebę bliższych kontaktów z Japonią i Chinami oraz utworzenia również tam konsulatów. Dzięki porozumieniom z Japonią w 1857 r. utworzono konsulat w Hakodate, w 1871 r. konsulat generalny w Jokohamie, a w 1874 r. kon-

\footnotetext{
${ }^{17}$ Zob. В. ХевРОлинА, Министерство Иностранных Дел России, s. 411. Chewrolina wskazuje tu przede wszystkim na zjednoczenie przez Prusy Niemiec i powstanie Cesarstwa Niemieckiego oraz na zjednoczenie Włoch. Jest to niewątpliwie prawda, gdyż oba te procesy spowodowały, że zanikła potrzeba istnienia części rosyjskich przedstawicielstw konsularnych w dawniej samodzielnych państwach niemieckich czy włoskich.

${ }^{18}$ В. ХевРолинА, Министерство Иностранных Дел России, s. 424.

${ }^{19}$ Очерк истории Министерства, s. 167.

${ }^{20}$ В. ХевРолИнА, Министерство Иностранных Дел России, s. 427-428.
} 
sulat $\mathrm{w}$ Nagasaki. Po zawarciu odpowiednich porozumień z Chinami utworzono w 1857 r. konsulat w porcie morskim Tianjin, a także w Urdze (w podległej Chinom Mongolii). W latach 1861-1862 działał rosyjski agent konsularny w Hankou (Wuchan) ${ }^{21}$.

W latach 1878-1881 utworzono kilka konsulatów generalnych na obszarze tzw. Bliskiego Wschodu: w 1878 r. we Wschodniej Rumelii, w Erzerum i w Salonikach, w 1880 r. w Jerozolimie i w 1881 r. w Jassach ${ }^{22}$.

W tym miejscu można wspomnieć, że w połowie lat 70 . pojawiła się konieczność uporządkowania składu przedstawicielstw zagranicznych i zwiększenia środków przeznaczonych na ich funkcjonowanie. Wynikało to między innymi ze zwiększenia zadań, jakie stały przed nimi. 4/16 grudnia $1874 \mathrm{r}$. minister spraw zagranicznych A. Gorczakow złożył w Radzie Państwa notę $O$ nowych etatach placówek zagranicznych. 20 stycznia/1 lutego $1875 \mathrm{r}$. Rada Państwa zaopiniowała ją pozytywnie. 4/16 lutego 1875 r. postanowienie Rady zatwierdził Aleksander II $^{23}$. Tym samym od 1/13 stycznia 1875 r. wprowadzano nowe etaty i uposażenie dla ambasad i misji, a od 1/13 maja 1875 r. dla konsulatów ${ }^{24}$.

Za panowania Aleksandra III, na początku lat 80. XIX wieku, Cesarstwo Rosyjskie dysponowało siecią konsularną liczącą 27 etatowych konsulatów generalnych, 46 etatowych i 28 nieetatowych konsulatów, 19 etatowych i 217 nieetatowych wicekonsulatów i 46 nieetatowych agentów konsularnych.

Ponieważ liczba nieetatowych konsulatów przewyższała liczbę etatowych, rosyjskie MSZ podjęło starania o zmianę tego stanu. Na przeszkodzie $\mathrm{w}$ realizacji tych zamiarów niejednokrotnie stawał jednak brak wystarczających środków finansowych. Utworzenie etatowego konsulatu było bowiem możliwe, gdy opłaty, jakie pobierali nieetatowi wicekonsulowie, osiągały w przybliżeniu taki rozmiar, jak wydatki potrzebne na utrzymanie konsula etatowego. W MSZ zdawano sobie sprawę, że nieetatowi konsulowie nie będą angażowali się w obronę interesów rosyjskich, zwłaszcza wtedy, gdy będą one sprzeczne $\mathrm{z}$ ich własnymi ${ }^{25}$.

\footnotetext{
${ }^{21}$ Tamże.

${ }^{22}$ ПСЗРИ, t. 53, часть 31878 г., Санкт Петербург 1880, s. 529-533; zob. też Очерк истории Министерства, s. 167.

${ }^{23}$ Kwestia ta została szerzej omówiona w: J.R. Budziński, Ministerstwo Spraw Zagranicznych Rosji, s. 82-84.

${ }^{24}$ ПСЗРИ, t. 50, часть 31875 г., s. 46-67.

${ }^{25}$ И. РЫБАЧЁНОК, Дипломатическое ведомство и российска дипломатия от берлинского конгреса до портсмутского мира (1878-1905 г2.), w: Очерки истории Министерства, т. 1, s. 467.
} 
W związku z tym, w miarę możliwości, MSZ starało się wprowadzać rozwiązania doraźne. Tak było do początku lat 90. XIX wieku. Jako przykład takich działań może posłużyć sytuacja spowodowana likwidacją misji przy miastach hanzeatyckich w 1883 r., która spowodowała, że wzrosło obciążenie konsula w Hamburgu. Dlatego zwiększono mu uposażenie i dodano do pomocy wicekonsula ${ }^{26}$. Wówczas też, po konsultacji z rządem niemieckim, opracowano rozgraniczenie okręgów konsularnych w Niemczech ${ }^{27}$. W $1884 \mathrm{r}$. utworzono także nowy wicekonsulat $\mathrm{w}$ Toruniu, ważny jako punkt obserwacyjny w pobliżu granicy niemiecko-rosyjskiej.

Na Dalekim Wschodzie Rosja posiadała znacznie mniej placówek konsularnych niż w Europie. Od stycznia 1882 r. pojawiły się konsulaty rosyjskie w Chinach, w miejscowościach Wuhan, Fuzhou, Turfan ${ }^{28}$. Port rzeczny w Wuhan i port morski w Fuzhou były ważne jako ośrodki wywozu herbaty oraz z racji ulokowania tam fabryk przez kilka rosyjskich firm.

Rozwój stosunków z Japonią spowodował potrzebę posiadania tam lepszej sieci placówek konsularnych. Mimo dostrzegania tego problemu Rosja posiadała tylko wicekonsula w Jokohamie i konsula w Nagasaki.

Jeśli chodzi o Azję, to w 1884 r. pojawiło się jeszcze przedstawicielstwo dyplomatyczne w Seulu, wicekonsul w Czemulpo oraz agenci konsularni w miastach portowych. W 1886 r. pierwszy dragoman przy misji pekińskiej otrzymał miano konsula generalnego. Z kolei 28 marca 1890 r. utworzono konsulat w Singapurze, który był ważnym portem dla handlu rosyjskiego ${ }^{29}$.

Cesarstwo Rosyjskie posiadało nielicznych przedstawicieli w Ameryce Północnej i Południowej. W 1883 r. utworzono nieetatowy konsulat w Portland w USA, w 1886 r. nieetatowemu konsulowi Rosji w Buenos Aires nadano rangę konsula generalnego w Argentynie. W 1886 r. w Urugwaju powołano nieetatowego konsula w Montevideo. Spowodowane to było pojawieniem się tam rosyjskich statków handlowych ${ }^{30}$.

W 1890 r. utworzono konsulat w Dżuddzie. Oficjalnie miało to zapewnić obsługę poddanych rosyjskich wyznających islam w ich drodze do Mekki. Jednak ważniejszym powodem było to, że przedstawiciel rosyjski w tym porcie mógł prowadzić obserwację rozwoju kolonii mocarstw europejskich w basenie Morza Czerwonego.

\footnotetext{
${ }^{26}$ ПСЗРИ, Собрание третие, t. 3, 1883 г., Санкт Петербург 1886, s. 232.

${ }^{27}$ И. РЫБАчЁНОК, Дипломатическое ведомство, s. 467.

${ }^{28}$ ПСЗРИ, Собрание третие, t. 2, 1882 г., Санкт Петербург 1886, s. 25.

${ }^{29}$ Rosyjska historyk Irina Rybaczenok wskazuje tu m.in. na fakt przewozu przez statki rosyjskiej Floty Ochotniczej herbaty o wartości ponad $12 \mathrm{mln}$ rubli; zob. И. РЫБАЧЁнОК, Дипломатическое ведомство, s. 468.

${ }^{30}$ Очерк истории Министерства, s. 181.
} 
Działalność placówek konsularnych została w 1893 r. zorganizowana na nowych zasadach, określonych w zatwierdzonej przez Aleksandra III 8/20 czerwca 1893 r. Taryfie opłat konsularnych ${ }^{31}$. Weszła ona w życie od 1 stycznia 1894 r.

W ostatnim roku panowania Aleksandra III Cesarstwo Rosyjskie posiadało 25 konsulatów generalnych, 62 konsulaty i 24 wicekonsulaty ${ }^{32}$.

Kolejny car, Mikołaj II, obejmując w 1894 r. tron, miał do dyspozycji sieć konsulatów usytuowanych w najważniejszych miejscach świata. Ich funkcjonowanie oparte było ma ustalonym w 1858 r./1859 r. Regulaminie dla konsulów w Europie i Ameryce i jego późniejszych modyfikacjach z 1875 i 1893 r. $^{33}$

Do opracowywania zmian dotyczących funkcjonowania przedstawicielstw zagranicznych przystąpiono dopiero w 1907 r., kiedy powołano specjalne komisje, obradujące z przerwami do 1914 r. Zajęły się one sprawami związanymi z zasadami odbywania służby konsularnej, zmianami dotyczącymi etatów konsularnych i działalności konsulów. W maju 1914 r. powołano z kolei komisję międzyresortową, a tworzyli ją przedstawiciele MSZ, Skarbu Państwa, Ministerstwa Handlu i Przemysłu, Kontroli Państwowej, Osobistej Kancelarii Jego Cesarskiej Mości, Kancelarii Państwa. Efektem jej prac było opracowanie wstępnego projektu zmian w organizacji etatów placówek zagranicznych $\mathrm{MSZ}^{34}$, który opierał się na dotychczas obowiązujących przepisach, ale gruntownie je modyfikował. Zawierał m.in. podział placówek zagranicznych MSZ na dyplomatyczne i konsularne, rangę kierowników tychże placówek, zadania stojące przed ambasadami, misjami, konsulatami, agencjami dyplomatycznymi. Zawierał również opis czynności, które mieli wykonywać przedstawiciele konsularni ${ }^{35}$. Na przeszkodzie jego wprowadzeniu stanął jednak wybuch I wojny światowej.

${ }^{31}$ ПСЗРИ, Собрание третие, t. 13, 1893 г., Санкт Петербург 1897, s. 437. Omówienie najważniejszych zapisów Taryfy opłat konsularnych oraz prac nad nią znajduje się w: J.R. BuDziŃSKI, Ministerstwo Spraw Zagranicznych Rosji, s. 93-95.

${ }^{32}$ Очерк истории Министерства, s. 181-182; И. РЫБАЧЁНОК, Дипломатическое ведомство..., s. 466.

${ }^{33}$ „Ежегодник МИД”, 1897, t. 34, s. 187. Informacje o obowiązkach etatowych i nieetatowych konsulów, ich uposażeniu i organizacji służby, wzory dokumentów, wysokości opłat można też znaleźć w oficjalnym dokumencie opublikowanym przez rosyjskie MSZ w 1912 r. - zob. Свод распоряжений Министерства иностранных дел по Департаменту Личного Состава и Хозяйственных Дел, С. Петербург 1912, s. 9-36.

${ }^{34}$ Szerzej problem działalności komisji zajmujących się reorganizacją służby konsularnej i zasad jej funkcjonowania został przedstawiony w: J.R. BuDZIŃSKI, Ministerstwo Spraw Zagranicznych Rosji, s. 202-213, 223-228, 251-261.

${ }^{35}$ Архив Внешней Политики Российской Империи (dalej АВПРИ), фонд (dalej ф.) 159, Департамент Личного Состава и Хозяйственных Дел (dalej ДЛСиХД), опись (dalej оп.) 731, дело (dalej д.) 21, листок (dalej л.) 175. 
Jeśli chodzi o zmiany, dotyczące usytuowania przedstawicielstw konsularnych, ich statusu, zwiększenia lub zmniejszenia ich składu, to przeprowadzano je głównie ze względu na zmieniającą się sytuację polityczną, na wzrost znaczenia jakiegoś państwa czy intensyfikację polityki prowadzonej przez Rosję w danym regionie świata. Rzecz dotyczyła zazwyczaj podniesienia bądź obniżenia rangi danej placówki czy też jej likwidacji lub przeniesienia. Propozycję zmian zgłaszał minister spraw zagranicznych do rozpatrzenia Radzie Państwa, a ta po ewentualnej aprobacie przedstawiała do zatwierdzenia władcy. Po 1906 r. w ten proces została jeszcze włączona Duma Państwowa.

Za panowania Mikołaja II, w okresie od 1895 r. do wybuchu I wojny światowej, do takich zmian dochodziło wielokrotnie. Dotyczyły one placówek w krajach Europy, Dalekiego Wschodu, Azji Środkowej, Afryki i Ameryki Północnej.

W 1896 r. zatwierdzono m.in. etat wicekonsulatu w Sofii, a także utworzono konsulaty generalne w Szanghaju i w Bagdadzie oraz konsulat w Isfahanie. W 1897 r. utworzono przedstawicielstwo w Maroku i w Syjamie. W 1898 r. zmieniono etaty generalnych konsulatów w Berlinie i Wiedniu, przeniesiono wicekonsulat $\mathrm{z}$ Brindisi do Bari $^{36}$ oraz utworzono konsulat na Malcie. W 1899 r. powołano do życia konsulat w Hongkongu, jako powód podając zwiększenie roli miasta i portu w polityce i handlu brytyjskim na Wschodzie oraz jako ważnego punktu połączeń morskich z portami całego świata ${ }^{37}$. W tym samym roku utworzono także stanowisko konsula w Kanadzie $^{38}$. W 1900 r. utworzono generalne konsulaty w Bombaju, a w 1901 r. w Buszehrze nad Zatoką Perską. Kolejne zmiany przyniósł rok 1902, kiedy to przekształcono wicekonsulat w Jokohamie w konsulat, a także utworzono konsulat w Mitrovicy, co miało wpłynąć na uzyskiwanie przez Rosję dokładnych informacji z regionu ${ }^{39}$.

\footnotetext{
${ }^{36}$ Сборник законоположений и инных титулов, служащих основанием назначения кредитов по смете расходов Министерства иностранных дел, С. Петербург 1909, s. 79-80. Rosyjskie MSZ podało dwa powody przenosin konsulatu. Pierwszym była zwiększona liczba rosyjskich pielgrzymów, którzy przybywali do Bari celem złożenia hołdu relikwiom czczonego przez prawosławie cudotwórcy Mikołaja. Ponieważ byli wykorzystywani przez miejscową ludność, w MSZ uznano, że należy zapewnić im opiekę rosyjskiej placówki konsularnej. Jako drugi powód podano to, że w Brindisi Rosja nie miała interesów handlowych, a Bari było czterokrotnie większe od Brindisi. Zob. tamże.

${ }^{37}$ Tamże, s. 82.

${ }^{38}$ Miejsca usytuowania konsulatu nie podano, co było częstą praktyką w publikowanych przez MSZ rozporządzeniach dotyczących placówek zagranicznych, ograniczano się tylko do podania kraju.

${ }^{39}$ Chodziło o sytuację polityczną w wilajetach tureckich, związaną z podejmowanymi wspólnie przez Rosję i Austro-Węgry działaniami odnośnie do tzw. reform w Macedonii; zob. И. РыБАчёНОк, Закат великой державы. Внешняя политика России на рубеже ХІХ-ХХ вв.: чели,
} 
W 1902 r. Cesarstwo Rosyjskie posiadało 29 konsulatów generalnych, 69 konsulatów, 39 wicekonsulatów (z czego 12 wicekonsulów przy konsulatach generalnych i konsulatach), co stanowiło łącznie 173 etatowe placówki za granicą. Oprócz tego Rosja posiadała powyżej 300 nieetatowych konsulów, wicekonsulów i agentów konsularnych ${ }^{40}$.

W 1903 r. ze względu na rosnącą rolę koreańskiego portu Fusan, stającego się centrum japońskiego handlu i działalności politycznej Japonii, przeniesiono tam konsulat $\mathrm{z}$ Masampo, które utraciło swoje znaczenie punktu obserwacyjnego działalności floty wojennej Japonii ${ }^{41}$. W 1906 r., w związku z uzyskaniem pełnej niepodległości przez Norwegię, utworzono m.in. przedstawicielstwo konsularne w Christianii. W 1908 r. w Mandżurii utworzono sieć placówek w randze konsulatów generalnych w Harbinie i Mukdenie, konsulatów w Kirinie, Cycykarze i Dalnym, wicekonsulatu w Kuanchengtze $^{42}$. W 1910 r. przekształcono generalny konsulat w Maroku w misję. W tym samym roku pojawiły się również konsulat w Pradze i generalny konsulat w Teheranie. W 1911 r. m.in. przeniesiono konsulat generalny z Amsterdamu do Rotterdamu. W 1912 r. utworzono konsulat generalny w Kalkucie, a zlikwidowano w Bombaju, oraz utworzono konsulaty w Kantonie i w Kobdo. W 1913 r. przekształcono konsulat w Urdze w konsulat generalny $\mathrm{w}$ Mongolii, $\mathrm{z}$ kolei misję w Maroku przekształcono w agencję dyplomatyczną i konsulat generalny ${ }^{43}$. W 1914 r. pojawił się jeszcze konsulat generalny w Albanii, co związane było z przyznaniem przez mocarstwa na konferencji pokojowej w Londynie niepodległości Albanii po wojnach bałkańskich lat 1912-1913. Ponieważ powołano wówczas Międzynarodową

задачи и методы, Москва 2012, s. 195-197. Rybaczenok, w odróżnieniu od urzędowego wydawnictwa Сборник законоположений и инных титулов, служащих основанием назначения кредитов по смете расходов Министерства иностранных дел z 1909 r., jako datę otwarcia konsulatu w Mitrovicy podaje rok 1903. Być może jest to błąd drukarski.

${ }^{40}$ Zob. Очерк истории Министерства, s. 206.

${ }^{41}$ Zob. Сборник законоположений и инных титулов, служащих основанием назначения кредитов по смете расходов Министерства иностранных дел, С. Петербург 1909, s. 99.

${ }^{42}$ АВПРИ, ф. 159 ДЛСиХД, оп. 731, д. 21, л. 289-290; Сборник законоположений и инных титулов, служащчих основанием назначения кредитов по смете расходов Министерства иностранных дел, С. Петербург 1909, s. 69-113; Очерк истории Министерства, s. 205; Сборник законоположений и инных титулов, служащих основанием назначения кредитов по смете расходов Министерства иностранных дел, С. Петербург 1909, s. 112-113. O rosyjskich placówkach konsularnych zob. С. ЧиРкин, Двадияать лет службы на Востоке. Записки иарского дипломата, Москва 2006, passim.

${ }^{43}$ Krok ten spowodowany był uznaniem przez Rosję Maroka za strefę wpływów francuskich, $\mathrm{w}$ związku z czym obniżono rangę przedstawicielstwa z misji do agencji i jednocześnie utworzono placówkę konsularną w randze konsulatu generalnego. 
Komisję Kontrolną, która miała sprawować kontrolę nad terenami nowego państwa, konsul generalny miał być jednocześnie komisarzem ze strony rosyjskiej $^{44}$. Również w 1914 r. wicekonsulaty w Adrianopolu, Jaffie i Wanie przekształcono w konsulaty i utworzono m.in. konsulat w Bukareszcie ${ }^{45}$.

Podsumowując powyższe rozważania, można stwierdzić, że rosyjskie przedstawicielstwa konsularne początkowo funkcjonowały na mocy porozumień między Cesarstwem Rosyjskim a innymi państwami. $Z$ upływem czasu i w związku z rozwojem stosunków handlowych wypracowane zostały oficjalne dokumenty (Regulamin konsularny, Regulamin handlowy, Taryfa opłat konsularnych), na których podstawie rosyjskie placówki konsularne prowadziły swoją działalność. Rozlokowanie przedstawicielstw konsularnych było związane początkowo z interesami ekonomicznymi państwa rosyjskiego, a w późniejszym czasie także z działalnością gospodarczą poddanych rosyjskich. Kolejnym czynnikiem, zwłaszcza w drugiej połowie XIX i na początku XX wieku, było również upowszechnienie się wyjazdów zagranicznych w społeczeństwie rosyjskim. Nie należy także zapominać o powstawaniu nowych państw. To spowodowało otwieranie rosyjskich przedstawicielstw konsularnych w nowych miejscach Europy i świata.

\section{BIBLIOGRAFIA}

\section{ARCHIWALIA}

Архив Внешней Политики Российской Империи, фонд 159 Департамент Личного Состава и Хозяйственных Дел, опись 731, дело (dalej д.) 18, 1868-1898; д. 21; д. 28 [Arkhiv Vneshney Politiki Rossiyskoy Imperii, fond 159 Departament Lichnogo Sostava i Khozyaystvennykh Del, opis' 731, delo (dalej d.) 18, 1868-1898; d. 21; d. 28].

\section{WYDAWNICTWA ŹRÓDŁOWE}

Полное собрание законов Российской империи (daleј ПСЗРИ). Собрание второе, т. 33, часть 21858 г., Санкт Петербург 1860 [Polnoye sobraniye zakonov Rossiyskoy imperii (dalej PSZRI). Sobraniye vtoroye, t. 33, chast' 21858 g., Sankt Peterburg 1860].

${ }^{44}$ Сборник законоположений и инных титулов, служащчих основанием назначения кредитов по смете расходов Министерства иностранных дел, Петроград 1915, s. 58. Zob. tеż: M. TANTY, Batkany w XX wieku. Dzieje polityczne, Warszawa 2003, s. 84-87; J. SKowroneK, M. TANTY, T. WASILEWSKI, Stowianie poludniowi i zachodni VI-XX wiek, Warszawa 2005, s. 449-450; S.K. PAVlowitch, Historia Bałkanów (1804-1945), przeł. J. Polak, Warszawa 2009, s. 242-243.

${ }^{45}$ Сборник законоположений и инных титулов, служащих основанием назначения кредитов по смете расходов Министерства иностранных дел, Петроград 1915, s. 25-63; А. ИгНАТЕВ, Е. КострикОВА, Дипломатия и деятельность МИД России от окончания войны с Японией до февральской револючии (1905-1917 г2.), w: Очерки истории Министерства, s. 548-549. 
ПСЗРИ, Собрание второе, т. 50, часть 31875 г., Санкт Петербург 1877 [PSZRI, Sobraniye vtoroye, t. 50, chast' 31875 g., Sankt Peterburg 1877].

ПСЗРИ, Собрание второе, т. 53, часть 31878 г., Санкт Петербург 1880 [PSZRI, Sobraniye vtoroye, t. 53, chast' 31878 g., Sankt Peterburg 1880].

ПСЗРИ, Собрание третие, т. 2, 1882 г., Санкт Петербург 1886 [PSZRI, Sobraniye tretiye, t. 2, 1882 g., Sankt Peterburg 1886].

ПСЗРИ, Собрание третие, т. 3, 1883 г., Санкт Петербург 1886 [PSZRI, Sobraniye tretiye, t. 3, 1883 g., Sankt Peterburg 1886].

ПСЗРИ, Собрание третие, т. 13, 1893 г., Санкт Петербург 1897 [PSZRI, Sobraniye tretiye, t. 13, 1893 g., Sankt Peterburg 1897].

Сборник законоположений и инных титулов, служащих основанием назначения кредитов по смете расходов Министерства иностранных дел, С. Петербург 1909 [Sbornik zakonopolozheniy i innykh titulov, sluzhashchikh osnovaniyem naznacheniya kreditov po smete raskhodov Ministerstva inostrannykh del, S. Peterburg 1909].

Сборник законоположений и инных титулов, служащих основанием назначения кредитов по смете расходов Министерства иностранных дел, Петроград 1915 [Sbornik zakonopolozheniy i innykh titulov, sluzhashchikh osnovaniyem naznacheniya kreditov po smete raskhodov Ministerstva inostrannykh del, Petrograd 1915].

Свод распоряжений Министерства иностранных дел по Департаменту Личного Состава и Хозяйственных Дел, С. Петербург 1912 [Svod rasporyazheniy Ministerstva inostrannykh del po Departamentu Lichnogo Sostava i Khozyaystvennykh Del, S. Peterburg 1912].

„Ежегодник МИД”, 1897, t. 34 [„,Yezhegodnik MID”, 1897, t. 34].

\section{OPRACOWANIA}

BUDZIŃSKI Janusz R., Ministerstwo Spraw Zagranicznych Rosji w okresie panowania Mikotaja II (1894-1917). Przemiany organizacyjne, Piotrków Trybunalski: Instytut Historii i Stosunków Międzynarodowych Uniwersytetu Jana Kochanowskiego w Kielcach, Filia 2015.

BudziŃski Janusz R., Piewczeskij Most. Z dziejów dyplomacji Imperium Rosyjskiego w latach 1802-1914, Piotrków Trybunalski: Instytut Historii i Stosunków Międzynarodowych Uniwersytetu Jana Kochanowskiego w Kielcach, Filia 2017.

Pavlowitch Stevan K., Historia Bałkanów (1804-1945), przeł. Jędrzej Polak, Warszawa: Wydawnictwa Uniwerstytetu Warszawskiego 2009.

SkowroneK Jerzy, TANTY Mieczysław, WASILEWSKi Tadeusz, Stowianie poludniowi i zachodni VI-XX wiek, Warszawa: Książka i Wiedza 2005

TANTY Mieczysław, Bałkany w XX wieku. Dzieje polityczne, Warszawa: Książka i Wiedza 2003.

ГРИГОРьЕв Борис, Повседневная жизнь иарских дипломатов в XIX веке, Москва: Молодая гвардия 2010 [GRIGORYEV Boris, Povsednevnaya zhizn' tsarskikh diplomatov v XIX veke, Moskva: Molodaya gvardiya 2010].

ИГНАТЕВ Анатолий, КостРИКОВА Елена, Дипломатия и деятельность МИД России от окончания войны с Японией до февральской револючии (1905-1917 г2.) [IGNATEV Anatoliy, Kostrikova Yelena, Diplomatiya i deyatel'nost' MID Rossii ot okonchaniya voyny s Yaponiyey do fevral'skoy revolyutsii (1905-1917 gg.)], w: Очерки истории Министерства Иностранных Дел России 860-1917 г2., т. 1, ред. Александр Сахаров, Москва: ОЛМА-Пресс 2002, s. 548-549 [Ocherki istorii Ministerstva Inostrannykh Del Rossii 8601917 gg., t. 1, red. Aleksandr Sakharov, Moskva: OLMA-Press 2002, s. 548-549].

КудРЯВцЕВА Елена, ПономАРЕВ Валерий, Дипломатия и МИД России во второй четверти ХІХ 6. [KudRYAVtSEVA Yelena, Ponomarev Valeriy, Diplomatiya i MID Rossii vo vtoroy chetverti XIX v.], w: Очерки истории Министерства Иностранных Дел России 860-1917 г2., т. 1, ред. 
Александр Сахаров, Москва 2002, s. 290-350 [Ocherki istorii Ministerstva Inostrannykh Del Rossii 860-1917 gg., t. 1, red. Aleksandr Sakharov, Moskva: OLMA-Press 2002, s. 290-350].

Очерк истории Министерства иностранных дел 1802-1902, Санкт-Петербург: Товарищество Р. Голике и А. Вильборг 1902 [Ocherk istorii Ministerstva inostrannykh del 1802-1902, Sankt-Peterburg: Tovarishchestvo R. Golike i A. Vilborg 1902].

РЫБАчЁНОК Ирина, Дипломатическое ведомство и российска дипломатия от берлинского конгреса до портсмутского мира (1878-1905 гг.) [RYBACHONOK Irina, Diplomaticheskoye vedomstvo i rossiyska diplomatiya ot berlinskogo kongresa do portsmutskogo mira (1878-1905 gg.)], w: Очерки истории Министерства Иностранных Дел России 860-1917 г2., т. 1, ред. Александр Сахаров, Москва 2002 s. 438-514 [Ocherki istorii Ministerstva Inostrannykh Del Rossii 860-1917 gg., t. 1, red. Aleksandr Sakharov, Moskva: OLMA-Press 2002, s. 438-514].

Рыбачёнок Ирина, Закат великой державы. Внешняя политика России на рубеже XIX-XX вв.: иели, задачи и методы, Москва: РОССПЭН 2012 [RYвАСнОNOK Irina, Zakat velikoy derzhavy. Vneshnyaya politika Rossii na rubezhe XIX-XX vv.: tseli, zadachi i metody, Moskva: ROSSPEN 2012].

Турилова Светлана, Из истории структуры МИД Российской Империи, „Дипломатический Вестник” 1993, nr 1-2, s. 69-75 [TURILOVA Svetlana, Iz istorii struktury MID Rossiyskoy Imperii, „Diplomaticheskiy Vestnik” 1993, nr 1-2, s. 69-75].

ХевРОлинА Виктория, Министерство Иностранных Дел России в период реформ (1856-1878) [Khevrolina Viktoriya, Ministerstvo Inostrannykh Del Rossii v period reform (1856-1878)], w: Очерки истории Министерства Иностранных Дел России 860-1917 г2., т. 1, ред. Александр Сахаров, Москва 2002, s. 351-437 [Ocherki istorii Ministerstva Inostrannykh Del Rossii 860-1917 gg., t. 1, red. Aleksandr Sakharov, Moskva: OLMA-Press 2002, s. 351-437].

ШАПКинА Алла, Образование МИД и деятельность российской дипломатии в первой четвер$m и$ XIX в. [SHAPKINA Alla, Obrazovaniye MID i deyatel'nost' rossiyskoy diplomatii v pervoy chetverti XIX v.], w: Очерки истории Министерства Иностранных Дел России 860-1917 гz., т. 1, ред. Александр Сахаров, Москва 2002, s. 239-289 [Ocherki istorii Ministerstva Inostrannykh Del Rossii 860-1917 gg., t. 1, red. Aleksandr Sakharov, Moskva: OLMA-Press 2002, s. 239-289].

Чиркин Сергей, Двадцать лет службы на Востоке. Записки царского дипломата, Москва: Русский путь 2006 [СнiRкIN Sergey, Dvadtsat' let sluzhby na Vostoke. Zapiski tsarskogo diplomata, Moskva: Russkiy put' 2006].

\section{ROSYJSKIE PRZEDSTAWICIELSTWA KONSULARNE I PODSTAWY PRAWNE ICH FUNKCJONOWANIA W LATACH 1809-1914: ZARYS PROBLEMATYKI}

\section{Streszczenie}

W artykule ukazano w zarysie powstawanie podstaw prawnych funkcjonowania rosyjskich przedstawicielstw konsularnych (Regulamin konsularny, Regulamin handlowy, Taryfa opłat konsularnych) w latach panowania ostatnich pięciu Romanowów. Przedstawiono także rozmieszczenie, liczbę i rodzaje placówek konsularnych. Ponadto zwrócono uwagę na czynniki wpływające na zmianę ich ulokowania oraz na ich likwidację bądź utworzenie (działalność gospodarcza poddanych rosyjskich, upowszechnienie się wyjazdów zagranicznych wśród społeczeństwa rosyjskiego, powstawanie nowych państw). Wskazano również na podległość organizacyjną przedstawicielstw konsularnych właściwym organom centralnym Ministerstwa Spraw Zagranicznych.

Slowa kluczowe: Cesarstwo Rosyjskie XIX-XX wieku; dyplomacja; placówki konsularne; akty prawne. 


\section{RUSSIAN CONSULAR MISSIONS \\ AND LEGAL GROUNDS FOR THEIR OPERATION \\ IN THE YEARS 1809-1914:}

AN OUTLINE

\section{$\mathrm{Sum} \mathrm{m}$ a r y}

The article presents an outline of forming the legal grounds for the operation of Russian consular missions (Consular rules, Commercial rules, Consular fees) during the rule of the last five Romanovs. The number, kinds and locations of consular missions were also presented. In addition, the work points out to factors which decided about relocation, liquidation or opening of new missions (economic activity of Russian subjects, popularisation of foreign travel among the Russian society, formation of new countries). The article also refers to the organisational subordination of consular missions to the respective central organs of the Ministry of Foreign Affairs.

Key words: Russian Empire of the $19^{\text {th }}$ and $20^{\text {th }}$ centuries; diplomacy; consular missions; legal acts. 